\title{
SOFT SYSTEMS METHODOLOGY: A Context within a 50-year retrospective of $\mathrm{OR} / \mathrm{MS}$
}

\author{
Arnold Reisman ${ }^{\alpha \beta}$ Muhittin Oral $^{\alpha}$
}

June 13, 2003

\begin{abstract}
"Soft Systems Methodology" (SSM) has been used in the practice of Operations Research/ Management Science (OR/MS) since the early $70 \mathrm{~s}$. In the $90 \mathrm{~s}$ it emerged as a viable academic discipline. Unfortunately, its proponents have articulated a dichotomy or mutual exclusivity between their approach and that of traditional systems thinking. This paper, provides a concise statement of the claimed differences between the two; discusses the complimentarity of one to the other; provides an extensive sampling over the life time of OR/MS of the rich non-SSM literature addressing the same issues as does SSM; and documents real-world studies that have simultaneously and productively used both approaches throughout time.
\end{abstract}

Key words: Soft Systems Thinking, Soft OR, SST, SSM, Operations Research, Management Science, OR/MS

The authors acknowledge the valuable contributions to the crafting of this paper by members of the MBA '03 class at Sabanci University. In particular, G.R. Cetinkaya, N. Merih, I.G.Ozyigitoglu, U. Ozdemir, B.C. Konduk, T. Ceyhan, U.Ozdemir, and P. Alan.

\footnotetext{
${ }^{\alpha}$ Graduate School of Management, Sabanci University, Istanbul Turkey

${ }^{\beta}$ Reisman and Associates, Shaker Hts, OH USA
} 
[T]here is more to OR than mathematics and the experimental sciences, there is a working version of the concept of value, with all its human and practical overtones.

Charles Hitch, (1956)

\section{Introduction:}

Had cavemen designed their carts with square wheels because such were easier to make, then over time, wear and tear, if not trial and error, would have naturally improved that invention. By anology, or perhaps counterpoint, Operations Research was born as a round wheel with round pegs. Its spectacular successes in World War II attest to that (Blackett (1962), Tidman (1984), Morse (1986), Roche (2002)). Over time however, the academic establishment has linearized both the "wheels" and the "pegs" into polygons if not perfect squares. Abbott (1988) and Corbett and Van Wassenhove (1993) claim that this was due to a "natural drift". If these respected authors are right and there is much evidence that they are, according to Pierskalla (1987), and Reisman and Kirschnick (1984), then management scientists have redefined what is "natural" and forced that science to "drift" in their direction of choice. In natural science such movements require the expenditure of otherwise usable resources. Any basic thermodynamics text will attest to that. Such resources were indeed plentiful to the academe of the $70 \mathrm{~s}, 80 \mathrm{~s}$ and even 90s. This was especially so in the USA.

In the world of addressing issues of management or in managerial problem solving, good systems thinking (ST) involves both "soft systems methodology" (SSM) and the time honored but recently dubbed "hard systems methodology" (HSM). It has been so, since the birth of Operations Research (OR)/ Management Science (MS) and ever since. This will be documented later. The need to "invent" soft systems thinking (SST) and SSM starting around 1972 [Checkland, Scholes (1999)] arose due to the well documented [Reisman and Kirschnick. (1994, 1995), Reisman (1995)], inbreeding process resulting in the emergence of a new paradigm within the OR/MS graduate education and published research. We shall label this paradigm as neoclassical $O R / M S^{l}$.

\footnotetext{
1“I once asked a well-known OR/MS friend who has written many books on the subject, to define OR/MS. He said, 'In one sentence, it is more or less optimization subject to constraints'. ' I said,' 'That is the
} 
With little doubt this neoclassical OR/MS justified the following statement to be made:

So we were lucky in our research programme that the failure of classic systems engineering in rich 'management' problem situations, broadly defined, was dramatic enough to send us scurrying to examine the adequacy of the systems thinking upon which systems engineering was based. Checkland, Scholes (1999)] pg. A11 (emphasis added)

However, as will be amply documented the bandwagon effect did leave some OR/MS workers unconvinced. Not all followed the emerging paradigm. And, not all perceived classic systems thinking to be as limiting as stated in the above quote. The fact is, that contemporaneously to SSM becoming an academic discipline at the University of Lancaster some practitioners of the art of OR/MS did good soft systems thinking (SST), without so calling it. Yes, counted among these are academics on both sides of the North Atlantic. Quite naturally they were following practices well established by the pioneers of OR/MS. As will be demonstrated, some of their work did indeed find its way into the mainstream or flagship journals. This however, was drowned out by the sheer volume of papers, based on the new OR/MS type of research paradigm ${ }^{2}$.

\subsection{Organization of this paper}

The remainder of this paper is organized as follows.

The Discussion section is subdived into several sections. In Section 2.1 wherein the classical systems thinking circa the 1960 s and 70 s is defined/ described based on a multiplicity of

problem solving part, how do you define the system in which the problems arise?' 'He said, 'We do not know yet enough to do that' ". Thomas L Saaty, (2000). As far back as the mid 1950s, a predisposition to these afflictions had been recognized. They were then dubbed as linearitis, and maximitis by Koopman, (1956). However, even within the neoclassical OR/MS paradigm, "Over the past 40 years, OR/MS has changed significantly. Today, the emphasis is on becoming a specialist, not a generalist. ....... a higher priority is placed on theoretical research than on applied research; issues of exactness and complexity stand in the way of providing answers to complex problems......today's graduates would not deign to cross the deterministic-probabilistic boundary". White, (1991)

${ }^{2}$ In 1968 a senior colleague in, then, a major operations research $\mathrm{PhD}$ granting department announced that no more applied OR dissertations should be approved. Fortunately he did not fully prevail.

However, in the 1980s a department editor of Operations Research rejected a paper submission that structured barter and countertrade practices in terms of a taxonomy and in terms of models. The text of that paper clearly pointed out that at the time over $35 \%$ of world trade was based on some form of reciprocity e.g., countertrade. The figure is higher at this point in time. (For the latest example refer to Poland's multi billion dollar "purchase" of F-16 fighter planes.) The rejection of that paper was based on the following reviewer argument: "Barter is negotiation, negotiation is game theory. If game theory is not used it is not operations research". That editor 
dimensions reclaimed from a 1979 (two years prior to publication of the first book on SST) text. Section 2.2 addresses the claimed differences between "hard systems thinking" (HST) and SST.

Section 2.3 discusses the Compatibility of HST and SST with subsections on the OR/MS literature dealing with stakeholders, (2.3.1); the OR/MS literature on implementation issues and model validation, (2.3.2.) and its relevance to SST claims; and the Systems Dynamics literature (2.3.3). Section 2.4 addresses SST and HST complementarities. Sections 2.5 deals with the emerging literature linking $H S T$ with $S S T$, and Section 2.6 provides a bibliography of classical ORMS literature involving both HST and SST. That bibliography spans the lifetime of OR/MS up to and including 1999. This year was chosen as cut-off for reasons to be explained. All this is followed by conclusions that were drawn from the above and further demonstrated by another bibliography provided in the Appendix.

\section{Discussion:}

We start with the following definition/description of the word system:

A system is a set of resources - personnel, materials, facilities, and/or information - organized to perform designated functions, in order to achieve desired results. (Reisman, 1979) pg 2.

Systems thinking (ST), then is basically thinking systemically with due attention paid to the dynamic and often nonlinear, stochastic processes of interaction between and across the above mentioned resources as well as the environment within which the system operates. The "differences" similarities, complementarities, and compatibilities or non-exclusivities between HST and SST follow throughout this paper.

No doubt SST provided an identity and some structure to a significant aspect of ST needed for the process of managerial problem solving. The kind of stuff that many practitioners have been using and many academics writing about prior to and ever since Checkland introduced his methodology and SST became a fashion among some academics and practitioners alike. Though not an entirely original idea in classical ST it emphasizes identification of the correct problem at the initial stages of the process of managerial problem-solving by introducing a methodology. SSM's contribution is

prevailed and obviously so did neoclassical OR/MS - a missed opportunity for the OR/MS community to record 
valuable in that that it handles the problem situation identification stage in an organized manner. Unfortunately, the Checkland, Scholes [1999] writings leave one with the impression that in managerial ST applications SST is of higher order and a needed replacement for HST. Specifically:

It was having to abandon the classic systems engineering methodology which caused us to undertake the fundamental thinking in chapters $2-4$ of $\mathrm{STSP}^{3}$. And it was this rethink which led ultimately to the distinction between 'hard' and 'soft' systems thinking. [Checkland, Scholes (1999) pg. A7 (emphasis added)

Moreover, they unequivocally state:

It is this shift of systemicity (or systemness ) from the world to the process of inquiry into the world which is the crucial intellectual distinction between the two fundamental forms of systems thinking, 'hard' and 'soft'. Checkland, Scholes (1999) pg. A10 (italics added).

Thus a dichotomy or a sense of incompatibility if not mutual exclusivity between SST and HST was introduced into the literature.

The dust has now settled. SST has been articulated, established and validated. It has been legitimised in many different ways. One of these is the fact that an SST publication was named as the " $50^{\text {th }}$ Anniversary [JORS], Paper" (Ranyard (2000)). SST is a recognized school of thought in both the real world and in many academic quarters. Hence a purpose may be served by showing its complementarity and non-exclusivity with "HST" in the solving of managerial problems.

\subsection{Classical systems thinking}

Recognizing that systems abound in the real world, Reisman (1979) suggested that their types can be classified along a three dimensional continuum as is shown in Figure, 1 below. One of the extreme points [corners] of this figure is labeled: "A large high technology socioeconomic system performing a one-of-a-kind function". Clearly, within this category one can subsume any given "process of enquiry into the world". This alone suggests that while dealing with socio-economic SST might have always been a part of "hard systems thinking". But one does not need to stop here to make this point. In discussing the various "Types of

and to do the "missionary" type work that Blumstein (1987) had called for.

${ }^{3}$ Checkland (1981) Systems Thinking, Systems Practice, 
Systems"4 three more system attributes were provided in that 1979 text. These distinguish system types based on whether they are Open or Closed, Adaptive or Non-Adaptive, ManMade or Natural, Systems. Furthermore the man-made systems are shown to include Conceptual Systems as well as Procedural Systems

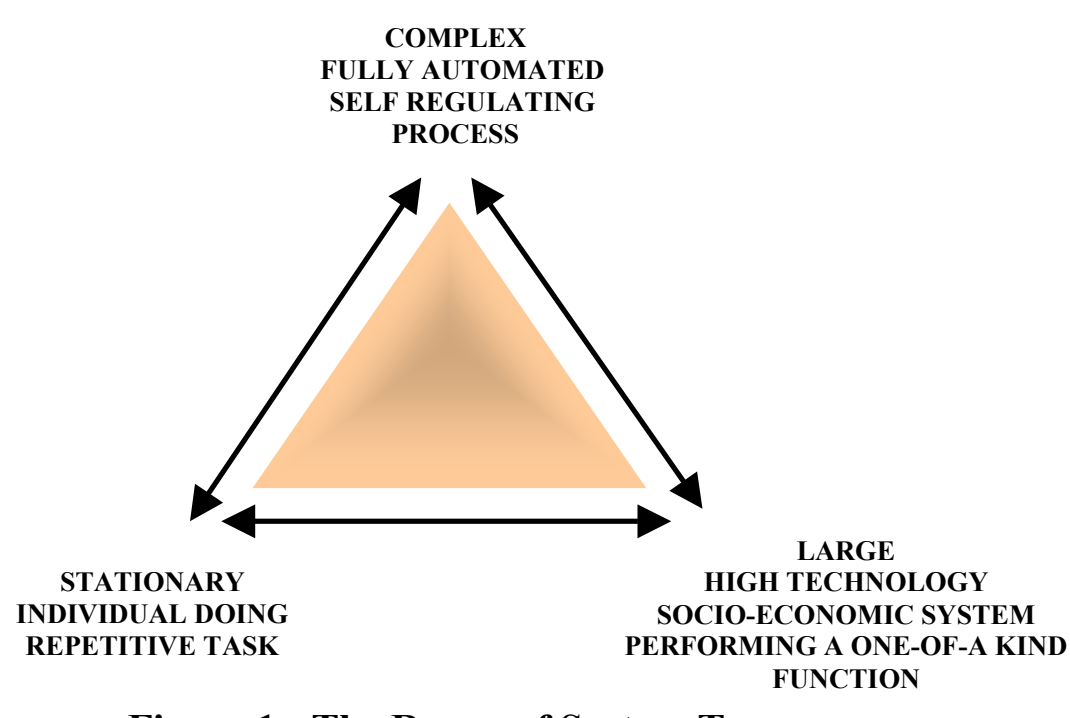

Figure 1: The Range of System Types

Thus within the Procedural Systems ${ }^{5}$ subcategory, one can surely subsume any given "process of enquiry into the world". The ever changing nature of some procedural systems is captured by the "adoptive" systems sub-category. In the discussion of "Adaptive versus Nonadaptive Systems" [pg 11], one finds that: "Adaptive systems react to the variations in their surroundings in direction that is favorable to the goals of the system. Each change in the environment evokes a favorable response from the system and thus leads to a new system".

The fact that these systems do not operate in isolation of their environment is captured by the "Open versus Closed Systems" delineation which clearly states that "in discussing social systems it is necessary to be very precise in defining terms such as openness or closedness - 'No man is an island...' An open system is therefore one that exchanges

\footnotetext{
${ }^{4}$ Reisman (1979) pg 10,

5 Such as "legal procedures, flows of patients in a clinic, flow of paper work", and especially relevant -

“diagnostic algorithms", Reisman (1979) pg 10, (emphasis added)
} 
materials, personnel, information money and so on with its surroundings" (Reisman (1979)) pg 11.

Given all the above, the "process of enquiry itself" neatly fits into the classical definitions of systems. So "HST" and SST are not mutually exclusive. In fact it is the hypothesis of this paper that they are complimentary if not one and the same and as stated at the outset, in good ST they are both used to a greater or lesser extent at different stages of the managerial problem solving process.

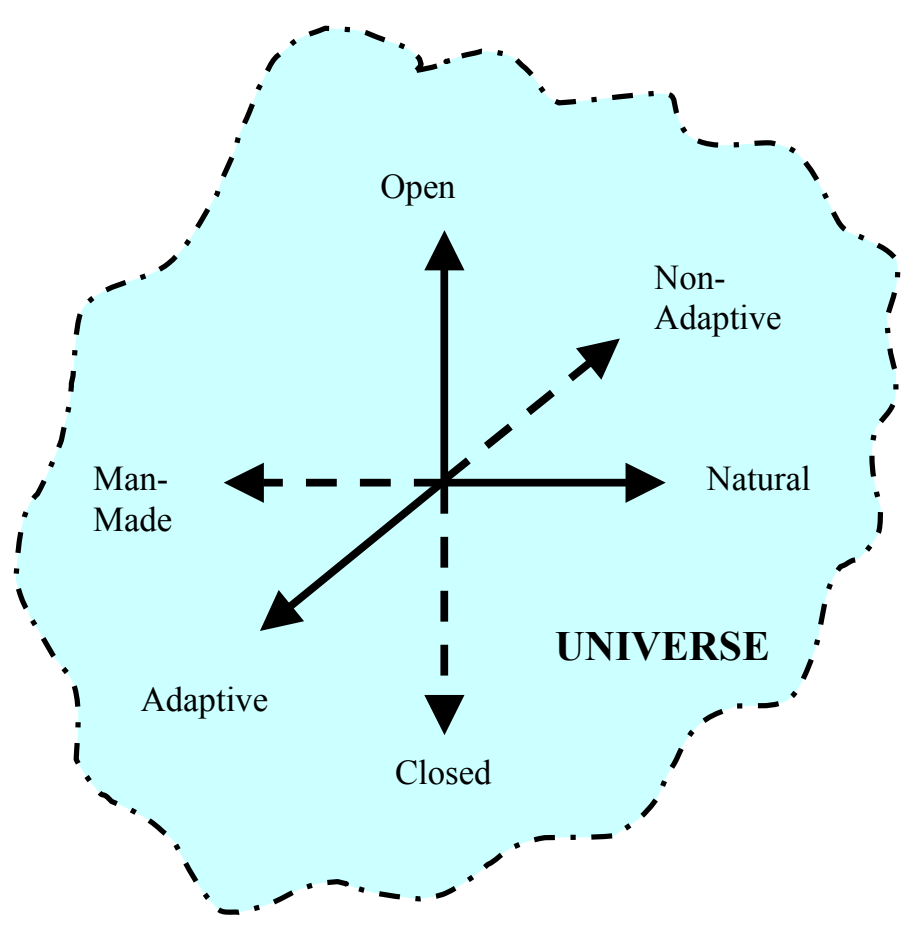

Figure 2. Attributes of system types ${ }^{6}$

\subsection{Claimed differences between HST and SST:}

The most concise statements these authors have found regarding the difference between HST and SST are:

'the system' is no longer some part of the world which is to be engineered or optimized, 'the system' is the process of enquiry itself" [Checkland, Scholes (1999) pg. 277 (emphasis added)

\footnotetext{
${ }^{6}$ This figure shows the classical descriptors of system types embedded within the SST type "universe" boundaries.
} 
and

[T] he use of the word 'system' is no longer applied to the world, it is instead applied to the process of our dealing with the world. [Checkland, Scholes (1999) pg. A10 (emphasis added)

Moreover, the SSM starts by "an urge to bring about improvement in a social system in which there is felt to be an ill-defined problem situation." Whereas hard system methodology starts by "an urge to solve a relatively well-defined problem which the analyst may, to a large extent, take as given, once a client requiring help is identified." [Checkland (1981) pg.190] (emphasis added).

These statements imply, if not outright state, that in classical systems thinking, managerial problems are taken as given. And, if that did not suffice; "systems solutions are created in isolation of the environment and when applied fail to cope with real-world situations" (emphasis added). On the other hand, "communication and interaction with the environment - the pillars of SST result in learning and feedback from the environment".

Above quotes leave no doubt that Checkland (1999), has little use for much if any of the rich body of very relevant knowledge developed and recorded prior to and since the launch of SSM.

\subsection{Compatibility ${ }^{7}$ of $H S T$ and $S S T$}

The "process of enquiry itself" the pillar issue of SST, as has been shown fits neatly into the classical definitions of systems. It is a procedural, adaptive, and open system. Also, in the extreme it is a large high technology socio-economic system performing a one of a kind function. Moreover, "adaptive [HST] systems react to the variations in their surroundings in direction that is favorable to the goals of the system. Each change in the environment evokes a favorable response from the system and thus leads to a new system". The complexity subject - the main issue of SSM - comes into play in this discussion. Human existence in a system makes the system open and dynamic. Consequently it is forever reacting and changing during the very process of inquiry. No doubt this creates difficulties for the system analyst. Some compared the situation to shooting at a moving target. So as will be further discussed SST is needed most in the

\footnotetext{
${ }^{7}$ Non-exclusivity is perhaps a better term.
} 
early stages of addressing management issues while HST is often necessary in the latter stages of problem solving.

Discussing a general model for production and operations systems analysis, in 1964 one of the authors of this paper wrote:

The model recognizes the dynamic aspects of enterprise behavior. ... This model is intended for use by the operations research practitioner who sees simulation primarily as a useful device for the analysis and synthesis of man/machine/process systems, to the management scientist, and particularly the management scientist with a socio-economic and psychological orientation who sees simulation primarily as a new tool for research into problems of human behavior in organizations. (Reisman and Buffa, (1964)), pg 65 (emphasis added)

However,

It is important to realize that an initial statement of needs can, after some preliminary analysis, turn into a considerably different statement of needs. A clearly stated technical description of a need can suddenly transform itself into one that is entirely different. The situation has not changed, the long-range goals may still be the same, but as the problem solver understands the situation better, he or she comes to realize that a more general and more appropriate need is in order. (Reisman (1979)) pg. 237

So SST statements to the contrary notwithstanding, in classical systems work the problem is not taken as 'given'. Thus it is possible to say that the two approaches are "compatible" in regard to the issues discussed. To be sure they are not mutually exclusive. In fact it is the hypothesis of this paper that in good ST they are both used to a greater or lesser extent at different stages of the managerial problem solving process and, that such practices can be traced back to the very founding of OR/MS.

\subsubsection{OR/MS literature dealing with stakeholders}

In his seminal text, over a decade before SST was conceived C. West Churchman, addressed the issues of OR/MS studies' stakeholders by noting that:

Stakeholders are those people who have a vested interest in the problem situation and its solution. They have, in one way or another, some leverage and influence on the development and use of a model. The 
success or failure of a model depends very much on the attitude and behaviour of stakeholders. In a sense, stakeholders are the model's clients. It is therefore quite important for model builders to identify the stakeholders for the model to be developed. The identification of stakeholders as a process itself generates some highly pertinent information about the perceptions and values of 'clients' regarding the problem situation. Churchman, (1961)

Two decades later Mason and Mitroff (1981) reinforced the issue in saying that identifying stakeholders is an easy way of generating the prevalent assumptions about a problem situation for "while it could be difficult to 'see' assumptions, most people can rather easily generate a set of stakeholders that bears on their perspective. From the stakeholders, it is but a short step to assumptions". Identifying the stakeholders thus appears to be a prerequisite for developing models having acceptable levels of conceptual and operational validity. This of course may lead to successful model implementation Oral and Kettani (1993).

The need for involving stakeholders was apparently recognized by the developers of SST as is attested by statements discussing various studies performed using SST:

SSM [is] most powerful when used by participants in a problem situation, the study was carried out by three managers...with some methodological help provided by outsiders. Checkland and Scholes (1999) pg 277 (emphasis added)

This was a highlighted study carried out by a team consisting of two insiders (civil servants) and three outsiders. Checkland and Scholes (1999) pg 278 (emphasis added)

So SST statements to the contrary notwithstanding classical systems work, places great emphasis on involving the stake holders. Thus it is possible to say that the two approaches are "compatible" in regard to the stake-holder issues discussed above.

\subsubsection{ORMS literature on implementation and model validation}

Related to the isssues of involvement of stake holders are issues of implementation of the recommendations resulting from an OR/MS study. This was was attested to in: 
From the project's inception, the team regarded itself as an extension of the $\mathrm{JCF}^{8}$ rather than as a separate entity. Ongoing involvement of Federation leadership was provided through establishment of an ad hoc Federation committee composed of lay leaders with extensive business experience and charged with overall project direction. The presence of this overseer committee and the inclusion of the JCF professionals on the research team ensured that implementation of results would receive continual attention. (Mantel et al., (1975)) (emphasis added)

Obviously this too is not a post SST practice.

In good managerial problem solving using systems thinking call it "hard" or "soft" one should not lose sight of the fact that a real world study is not worth much unless it is successfully implemented and achieves the desired outcomes.

The basis for this discussion is the recognition that systems studies should be structured and conducted in such a way that the probability of successful implementation is maximized. Therefore, implementability of methods used and results obtained is imperative. To achieve this planning for implementation, the design of the task force, the relationship with the user, and the critical evaluation of results are singled out as important factors. The involvement of the ultimate user may well be the most important one. .... The common element underlying all these strategies is communication, defined in the widest sense. Success is impossible without enlightened users and sponsors who have achieved ownership of the study. Only then will a climate of confidence favor successful implementation. (Reisman (1979)) pg 261 (Emphasis added)

And, Oral and Kettani (1993) addressed the modeling and validation process in operations research from several different "facets" or perspectives. Among these are both the managerial (model user's/implementor's) perspective, and the model formulator's perspective. They also provide a fairly lengthy bibliography of work addressing the very issues that created SSTs "raison d'ettre". That bibliography has been expanded as shown in Appendix $A$ and it is summarised in Table 1 on a timeline 1953- $1997^{9}$ timeline.

A look at the history of model validation in operations research indicates that validity has been interpreted in different ways depending on the epoch and on the context. During the early years of operations research,

\footnotetext{
${ }^{8}$ Jewish Community Federation.

${ }^{9}$ This allows two years for the preparation of Checkland (1999).
} 
the concept of model validity included, usually only implicitly, ideas like usefulness, usability, representativeness ${ }^{10}$ and cost considerations, albeit their relative importance varied. For the pioneers of operations research, scientists like Blacken, Waddington, Morse, Kimball, and Koopman, the issues of usefulness, usability and cost were naturally resolved through an effective and sound modeler-user interface Landry et al. (1983) (Emphasis added)

\section{Moreover,}

The subject of implementation of systems has been of great concern to the many professions which do systems analysis. The concern is due to the fact that too many completed systems studies have never been implemented. The question being raised is why? Clearly there is no one answer which is universally applicable. Research into the matter is in its infancy. [circa1979]... However, based on years of reflection on systems studies performed in organizations, some do's and don'ts of systems analysis practice have emerged. (Reisman (1979)) pg 261 (Emphasis added)

So SST statements to the contrary notwithstanding, classical systems work places great emphasis on an effective and sound modeler-user interface. Thus it is possible to say that the two approaches are not mutually exclusive. They are "compatible" in regard to model validation issues discussed above.

\subsubsection{Relevance of Systems Dynamics literature}

The following quote from the founder of Systems Dynamics speaks for itself:

Systems Dynamics, systems thinking and soft operations research (soft OR) all aspire to understanding and improvement of systems. In all, the first step interprets the real world into a description used in following stages. In systems dynamics, description leads to equations of a model, simulation to understand dynamic behavior, evaluation of alternative policies, education and choice of a better policy and implementation. Case studies, systems thinking and soft OR usually lack the discipline of explicit model creation and simulation and so rely on subjective use of unreliable intuition for evaluating the complex structures that emerge from the initial description of the real system. Nevertheless, systems thinking and soft OR, with emphasis on eliciting information from real-world participants, should

\footnotetext{
10 “The term 'representativeness' in this paper is used to mean 'the extent to which the model fits the real system either in terms of structure and mechanism or in terms of output, depending on the context of the problem".
} 
contribute useful insights to systems dynamics. Conversely, the model creation and simulation stages of systems dynamics should contribute rigor and clarity to systems thinking and soft OR. Forrester, (1994)

So SST statements to the contrary notwithstanding, the systems dynamics approach is "compatible" with SST.

\subsection{Complimentarity of $H S T$ and $S S T$}

This section will address the complementarity between the two thinking paradigms

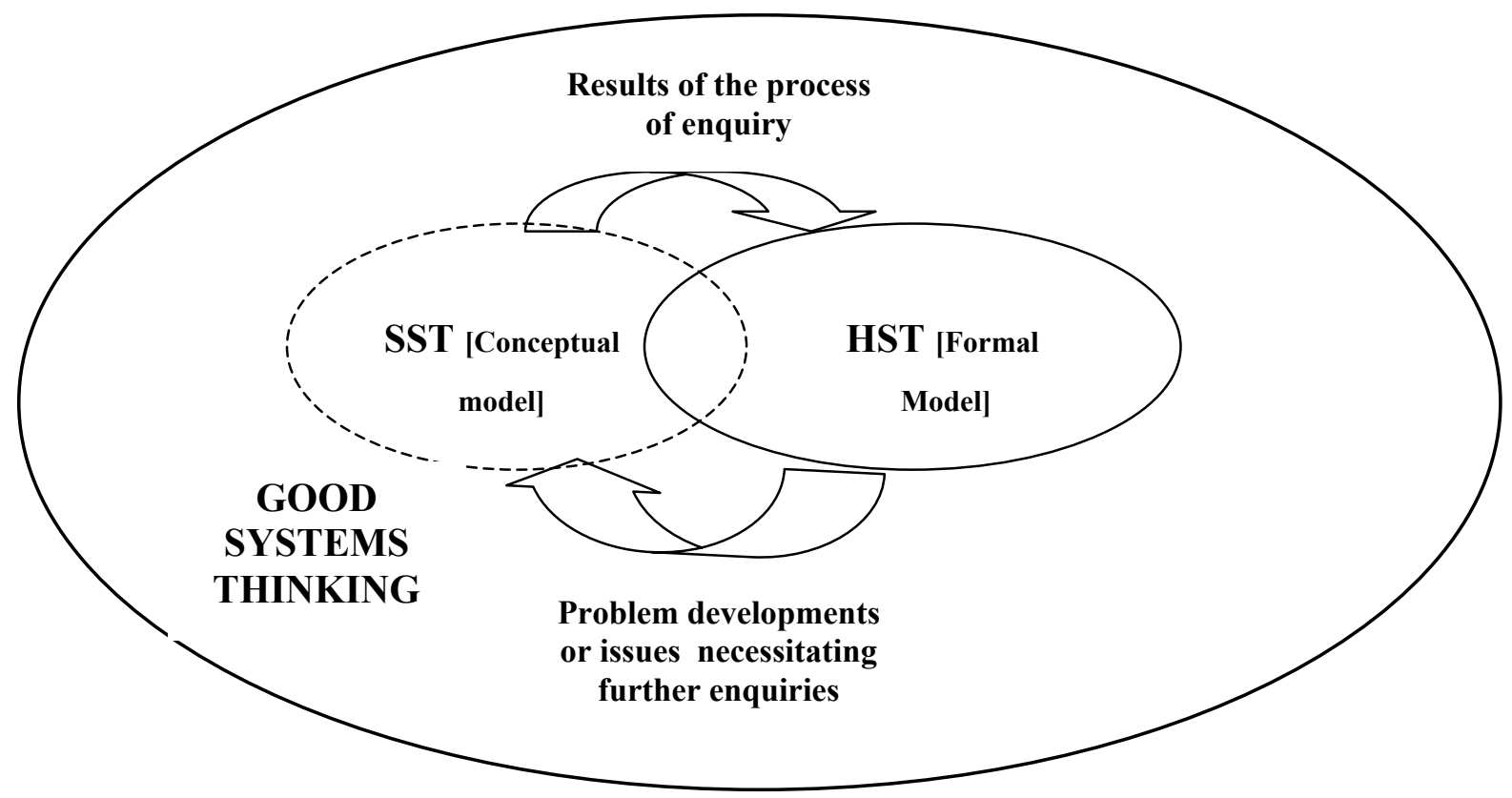

Figure 3. Depiction of Good Systems Thinking

Given the prevailing state of the art in SST and neoclassical OR/MS, it can be said with some confidence that SSM and HSM need each other to solve the right problem in the right way. The complementarity of SSM with HSM alluded to in the Section 2.3.3 is depicted in the Figure 3. In dealing with managerial (real-world) issues both 'soft' and 'hard' systems thinking needs to be applied respectively to a greater or lesser extent at different stages of the project lifecycle.

Admittedly oblivious to stirrings that created SST on the other side of the Atlantic, Reisman (1979) addressed the above issues in terms of the differences in the mentality 
needed at the early project stages as compared to those needed further along the project time line. In the earlier project stages the generalist mentality ${ }^{11}$ must dominate so as to properly abstract the essence from what is typically a very noisy and dynamic environment. Hence the greater need for SSM assuming of course that the practitioners involved have broad

perspective. Since the latter stages of the project are more technical/operational, they require a more concrete and technical mentality.

Hence, the greater the need for HSM skills ${ }^{12}$. This should not be interpreted to mean that early project/problem situations require only SST and the subsequent project problem stages require HSM exclusively. There may well be cases where "soft" problem situations occur late in a project's life as well as "hard" situations early in a project's life.

Additionally, even the most complex management problem solving situations can be characterized by a number of distinct phases namely; recognition of needs, statement of the problem, formulation of the value model, synthesis of alternatives, analysis and testing, evaluation and decision making. Reisman (1989) pg 234 , shows these to be part of an iterative process of problem solving.

It is difficult or even sensible to separate hard and soft systems thinking since in most studies both issues need to be addressed throughout the project's life cycle. For instance, classical systems analysis calls for a fairly thorough documentation of the system prior to any analysis or attempted redesign. That phase was and is still referred to as a systems description. Specifically:

[A] description of the system in terms which are both compact and operationally meaningful can be used by an organization to understand, to teach, to change-design/redesign, improve, or optimize- and to control the system or any unit thereof. Systems analysis in its limited scope can be and often is used as an end in itself. Specifically, the results of systems analysis yield answers to the question "who does what, where, when, why and how?" (Reisman (1979)) pgs 4- 5

\footnotetext{
11 "Unfortunately, in admission and graduation decisions faculty appear to make a Type I error. ......failing a student [applicant ] who should pass an exam" and be admitted. White (1991). Hence we select based on proven intelligence. This tends to systematically select out the mentality needed in the early stages of structuring real-world problems. "In recruiting graduate students, we are not particularly concerned about the long term implications ... of our selection". White (1991).

${ }^{12}$ Recently Saaty (2000) addressed the same issue by stating: "To analyze problems in detail, we need intelligence. But we need creativity to synthesize and create structure to obtain higher level abstraction[s] of problems." However, even within the neoclassical OR/MS paradigm, "Over the past 40 years, OR/MS has changed significantly. Today, the emphasis is on becoming a specialist, not a generalist. ....today's graduates would not deign to cross the deterministic-probabilistic boundary". White, (1991)
} 
Without any doubt SSM appears to address those very issues when soliciting answers to:

1. What is the real problem?

2. What are the goals or objectives to be achieved given the conflicting perceptions about the problem situation .

3. What are the constraints?

4. Who are the players, the stakeholder?

5. Who are the beneficiaries?

6. Who are the regulators?

7. What part of the world is involved? or, What is the system?

8. Given the system above, how does it perform its functions?

9. What are its subsystems and so on.

10. What are or what should be the evaluation criteria for system performance

To meaningfully address complex managerial issues and problems in real world contexts each of the above questions must be answered. The answers are not easily found and those that are may indeed be wrong. The above process is like that of a good physician addressing a sick patient for the first time. In addition to hearing the symptoms, he or she must collect relevant family and patient histories, study the patient's chart or medical record, do a physical, hands-on exam, order lab and other tests prior to making a diagnosis. All this is done to lay the basis for deciding on a treatment plan. In systems applications to managerial problem solving the above is analogous to what is called a "Systems Description". An illustration of such for an industrial inventory control study can be found in Reisman et al., (1972) Chapter 2, pgs. 8-31.

Non of the initial responses from any of the stakeholders should be taken as given ${ }^{13}$. This is especially so with question 10 above. History is replete with examples of good organizations in the private (for-profit and not-for-profit) and public sectors having been sent into a downward spiral or a self destruct mode by (non obviously) wrong criteria being used to evaluate performance, (Reisman et al., (1972) Chapter 3, pgs. 32-37). Many a corporate

\footnotetext{
${ }^{13}$ Based on much personal experience, dating back to the WW II days, Hugh Miser, one of the grand old men of OR/MS recognized this issue in Wagner et al., (1989). "When an OR worker is called on to help with a problem, it is common experience for the client to describe the problem in terms that later turn out not to be incorrect, or to state expectations that later turn out to be mistaken.
} 
executive with the best of academic credentials is facing a long jail sentence at the time of this writing. At least one wag was known to say: "Be careful what it is that you measure 'cause what you measure is what you will get." In OR/MS this problem was recognized way back by B. O. Koopman (1956)

The strength of SST lies in getting a good handle on a description of the system. Whether such description is "expressed in terms which are both compact and operationally meaningful and which can be used by an organization to understand, to teach, to changedesign/ redesign, improve or optimize- and to control the system or any unit thereof " is fairly dependent on the skills of the SST professionals. Classical systems analysis relying on effective use of text, graphics, mathematical or conceptual models teaches such skills as in Reisman 1989) among many many others.

To elicit all this information from the minds of decision-makers is a non trivial matter. A systems view must be taken at all times while defining the system to be studied. Hence, the virtue of SST. Again, "the structuring which derives from consciously enacting the system of enquiry enables apparently disparate studies to be examined as a group through the epistemology which SSM provides," Checkland and Scholes (1999) pg. 277. This notion was de facto and indeed the basis used in each and every study listed in Appendix B. It may be useful to note that the dates of such publications begin in 1969. In the industrial inventory control study (Reisman et al., (1972)), the task force comprised three middle-level company managers two operations research faculty members and two of their graduate students ${ }^{14}$. Moreover, on a monthly basis, the task force reported to and interacted with the company's Executive Committee.

However, the concept goes further as involving all of those involved with the system in the discussion about proposed changes.

By this way an element of action research enters into the process. This makes it more likely that any solutions will be both technically sound and culturally acceptable. This process of consultation and involvement also introduces an element of iteration, whereby changes evolve in a number of steps and with the consensus of all of those involved. The iteration also allows a gradual coming together of all people involved. Kirk (1995)

\footnotetext{
${ }^{14}$ Thirty years after the completion of that study and implementation of it results, one of them, Dr. Muhittin Oral is now the founding Dean of the Graduate School of Management, Sabanci University, (Istanbul, Turkey) where all MBA students are required to perform, on a team basis, a management study using systems thinking in a real world enterprise.
} 
Without any quarrel, "the structuring which derives from consciously enacting the system of enquiry enables apparently disparate studies to be examined as a group through the epistemology which SSM provides, Checkland and Scholes (1999) pg. 277 (emphasis added)

\subsubsection{Literature linking hard and soft systems}

A "multi-methodology" literature was spawned as the SSM/HSM dichotomy became a widely accepted fact. The most visible articles in this emerging discipline are: Mingers and Brockerlesby (1997), Jackson and Keys (1984), Jackson (1989) and(1993), and (1993), Mingers (1993), Mingers and Gill (1997) and Muller-Merbach (1994). In addition the "critical systems thinking" literature was created (Mingers (1992), as well as another linking the above two, (Mingers (1993), Jackson (1997), Ulrich (2003)). These literatures stress the need to be critically aware of "shortcomings" in both SSM and HSM. In the late 1980’s and early 1990’s they stressed new integrative systems perspectives and 'methodological pluralism'. After critical examination of the pros and cons of the different systems approaches, the most appropriate are selected. This according to the proponents, allows one to address a wider range of issues than is possible with a single approach. Moreover, the multi-methodology of Mingers and Brocklesby (1997) recommends the usage of hard and soft systems approaches in combination to deal with different aspects of a problem situation.

Consequently, critical systems thinking not only probes the complementarity of soft systems thinking and hard systems thinking but also aims to indicate which systems approach is more suitable to solve what kind of a problem. In that sense, critical systems thinking offers guidance in selecting a particular systems approach, hard or soft, as system improvement evolves from problem structuring to problem solving.

\subsection{Classical OR/MS literature involving both HST and SST}

Any serious attempt at studying "Soft Systems Thinking/Methodology" especially in juxtaposition to "hard systems", may not overlook the relatively voluminous literature concerned with model validation (Oral and Kettani 1993) and legitimisation (Landry et 
al. $(1983,1996)$, that had been in the public domain ever since the emergence of OR/MS e.g. back to WWII, (Blackett (1962)). Nor can such an attempt overlook the rich literature dealing with issues of implementation of study results and the related issues of structuring the study task force and giving due consideration to all stakeholders and on structuring of the study team or task force. "The early literature on operations research repeatedly mentioned the interdisciplinary nature of OR teams" Rothkopf in Wagner et al., (1989). Interestingly and apropos that sentence is followed by, "The reduction in the emphasis on the interdisciplinary nature of OR has coincided with a reduction in the perception of the usefulness of OR." One might add that both of these "reduction[s]" coincided with the emergence of neoclassical OR/MS and institutional loss of memory. So, assuming the SSM/HSM dichotomy as fact, in his 'forward' looking article "Beyond Methodology Choice...." Ulrich (2003), states: "Contrary to present conceptions of methodological pluralism or 'complementarism', boundary critique must not be subordinated to methodology choice, for it is constitutive of all critical inquiry and practice. These considerations lead to a reconsideration of CST [Critical Systems Thinking], and to a new view of reflective professional practice in general, as critically systemic discourse." The pioneering generation of OR/MS would find this statement, coming in (2003), somewhat amusing. They practiced it and they wrote about it. The Appendix provides a rich sample of such literature. Moreover, this sampling is subdivided into articles addressing the issues involved from a philosophic or a theoretic perspective appearing in Appendix $A^{15}$, and those discussing real-life studies having results that were implemented appearing in Appendix $B^{16}$.

Appendix $A$ articles, are significant in that over the entire life-span of OR/MS, they represent the great amount of attention given to the issues that SST claims to have uniquely addressed. On the other hand, Appendix $B$ articles, could have never seen the light of day if its authors did not apply skills gained from the rich experience of OR/MS pioneers "like Blackett, Waddington, Morse, Kimball, and Koopman," who quite "naturally resolved through an effective and sound modeler-user interface" (Landry et al. (1983) (Emphasis added)) the kind of issues that SST claims as its own.

\footnotetext{
${ }^{15}$ The selection of this set was predicated on obtaining a time-wise uniform distribution of papers having the widest visibility to academics and practitioners worldwide.

${ }^{16}$ The selection for this set was unabashedly opportunistic.
} 
Interestingly, Checkland (1999) a book which "[i]ncludes a 30-year retrospective" on SST has only two of the Appendix A entries listed in its Bibliography section. These are: Blackett (1962) and Schon (1983). 
Table 1:

The non-SST Literature:

Articles in archival journals, chapters in books and books dedicated to addressing the philosophic or theoretic notions underlying $S S T$

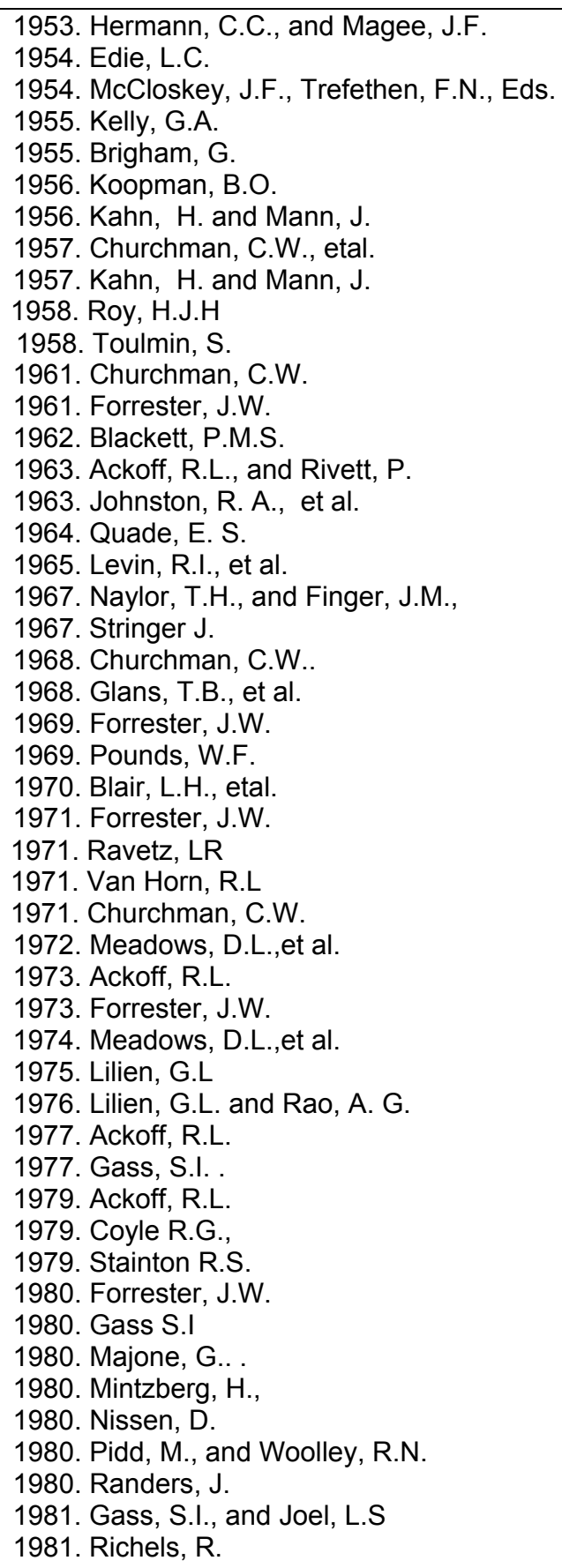

\footnotetext{
${ }^{17}$ This book inspired a very lively discussion of OR/MS analysts' approaches tio addressing a real world problem, Miser (2000), 225-228, Keys (2000), 229-232, Smith (2000), 233-234 and Mitchell, (2000) 235.
} 
Although the "process of enquiry" was the crux issue discussed by seasoned OR/MS workers ${ }^{18}$ on both sides of the North Atlantic, SST this is hardly acknowledged in Checkland (1999)). On the other hand, reviewing the "30-year retrospective" of SST (Checkland (1999)) one finds a strange set of anomalies. Nowhere in the book can one find any mention of the noble efforts by professional societies on both sides of the North Atlantic to correct the wrongs SST claims to have corrected ${ }^{19}$. Such efforts included; annual competitions for the best real world application of OR/MS; the sections of journals and the sessions at each annual meeting dedicated to OR/MS practice and or to the teaching of OR/MS; the "Ombudsman" columns; the many non-SST articles addressing the very issues claimed as cause for SST replacing HST; the many articles based on serious meta (research on) research, reaching similar conclusions. And, nowhere in the book can one find testimonials to people who never wavered from the original paradigm of OR/MS as did many of the newcomers. There are many such testimonials to be found as for example:

Over his $50+$ year career William Wager Cooper has been totally unaffected by the very significant "natural drift" away from the "swamps of relevance" and from "missionary work" toward "introversion", "loss of relevance", "devolution", and "mechanical optimi[zation]", which took place during that same time-frame among the OR/MS academic establishment in the United States. History has borne out that $W$. W. Cooper was correct in keeping his course firmly rooted in the very "swamps of relevance" while significantly and meaningfully extending and expanding the theoretical basis of OR and of MS, giving other professions a sought after tool and thus enabling the kind of "missionary work" that Blumstein called for.

Reisman et al. (2003) (Emphasis added)

\section{Conclusion:}

James G. Roche, (2002), in his Omega Rho Distinguished Lecture, articulated the problem most recently.

The original ops [operations] researchers understood that to be effective, they needed teams of mathematicians, historians, military theorists,

\footnotetext{
${ }^{18}$ One a sitting Editor-in-Chief (George Michell) of a UK based journal (Omega) another a former president of ORSA (Hugh Miser)

19 "First where humans participate in operations that are studied by OR, OR will have to deal realistically with human behavior. This is just a particular instance of the formulation issue ...discussed" Rothkopf in Wagner et al., (1989).
} 
psychologists, and economists among others. They understood the natural complexity of war, to include second-order effects. War is not just a mechanical or scientific act. In practice, it is an art and science that operates in a foggy sea of strategy, politics, and luck. .... Somewhere along the lines, this was lost as a fundamental concept of military operations analysis.

Because one might add that it was also lost on the majority of the OR/MS academic community $^{20}$, it is fair to allow for the claimed differences between SST and ST or "HST". Having said that, it must be recognized that the two while different are mutually supportive. Succinctly put, SSM plays the greater role in identifying, defining and solving the right problem and HSM, plays a greater role in solving that problem the right way. Moreover, SST is crucial to enhancing the probability that the study results will be implemented by the host/client organization. As is shown, there is a plethora of evidence suggesting that SSM's founding fathers cannot claim exclusivity in this rather crucial arena nor can they claim inventors' rights. OR/MS has been concerned with the very same issues starting with its role in WW II and ever since. The issues had been addressed at all times and the concepts have been practiced at all times. To be sure, over time much of what was being published in the flagship OR/MS journals, and much of what was "being taught and researched at many universities including some of the very best" created the need for some reaction, hence, SSM. Unfortunately the rhetoric in its 'seminal' texts has left many newcomers to OR/MS confused ${ }^{21}$ and some of us old-timers perplexed.

\section{References:}

Abbott A. The system of professions: an essay on the expert division of labor. University of Chicago Press, Chicago, IL, 1988. approaches. Omega (2000), 229-232,

Blackett, P.M.S. (1962). Studies of war. Hilland Wang, New York.

Blumstein, A. (1987) The Current Missionary role of OR/MS, Operations Research 35, 926-929.

Checkland, P. (1985). Achieving 'Desirable and Feasible' Change: An Application of Soft Systems Methodology, Journal of the Operational Research Society, 369821 831

Checkland, P. and J. Scholes (1999) Soft Systems Methodology in Action, J. Wiley and Sons, New York

\footnotetext{
${ }^{20}$ Please recall footnote 1

${ }^{21}$ Misled may be a more appropriate word.
} 
Checkland, P.,(1981) Systems Thinking, System Practice: Includes a 30-Year Retrospective, J. Wiley and Sons, New York

Churchman, C.W. (1961) Prediction and Optimal Decision. Prentice-Hall, Englewood Cliffs.

Corbett CJ, Van Wassenhove LN. The Natural Drift: What Happened to Operations

Forrester, Jay W., 1994.System Dynamics, Systems Thinking and Soft OR. Systems Dynamics

Review. Vol: 10,No:2

Green, S. and contributors (1998). The Debate So Far, retrieved on December 8, 2000 from the World Wide Web http://members.aol.com/acockburn/papers/methyspace/methyspace.htm

Hitch, C., (1956) "Comments" on Koopman, B.O. (1956), "Fallacies in Operation Research", Address to the Fourth Annual Meeting of the Operation Research Society of America. May 10

Hong, M., Paulson, J., Springl, M., \& Wong, R. (1999). SENG 613 Managing the Software Lifecycle, [Web Page]. Software Engineering Network - University of Calgary. Available: http://sern.ucalgary.ca/ paulson/SENG613/seng613-ssm.htm [2001, 11/1/03]

Jackson, M. (1989), "Which Systems Methodology When? Initial Results from a Research Program" in Systems Prospects". The Next ten years of Systems Research, ed. R. Flood M. Jackson, and P. Keys. Plenum, New York.

Jackson, M. (1993), "The System of Systems Methodologies: A Guide to Researchers." Journal of the Operational Research Society 44, 208-209.

Jackson, M. (1997), "Pluralism in Systems Thinking and Practice" In Multi Methodolgy: Theory and Practice of Combining Management Science Methodologies. Ed. J Mingers and A. Gill. Wiley, Chichester.

Jackson, M. and Keys, P., (1984), Towards a system of system methodologies, Journal of the Operational Research Society, 35, pp.473-486

Keys, P. Sockwear and its analysis: an examination of the Jones and Morse-Jones

Khisty, C.J., (1995), "Soft Systems Methodology as Learning and Management Tool", Journal of Urban Planning and Development, 21, No 3 pp 92.

Kirk, D. (1995) “'Hard and Soft Systems: A common paradigm for operations management?", International Journal of Contemporary Hospitality Management, 7 No. 5, pp. 13-16, MCB University Press

Koopman, B.O. (1956), "Fallacies in Operation Research", Address to the Fourth Annual Meeting of the Operation Research Society of America. May 10

Landry, M., Banville, C., and Oral, M. (1996), "Model legitimisation in Operational Research", European Journal of Operational Research, 92, 443-457.

Landry, M., Malouin, J.L., and Oral, M. (1983), "Model validation in Operations Research", European Journal of Operational Research 14, 207-220. linus.socs.uts.edu.au/ jim/bpt/ssm.html [2003, 11/1/03].

Mason, R.O. and Mitroff, I.I. (1981). Challenging Strategic Planning Assumptions-Theory, Cases and Techniques. Wiley, New York

Mingers, J. (1992) "Recent Developments in Critical Management Science", Journal of the Operational Research Society, 44, 849-850 
Mingers, J. (1993), "Systems Methodologies and Critical Management Science”, Journal of the Operational Research Society 43, 1-10

Mingers, J. (1997), Towards Critical Pluralism. In Multi Methodolgy: Theory and Practice of Combining Management Science Methodologies. Ed. J Mingers and A. Gill. Wiley, Chichester.

Mingers, J. Gill. A., ed. (1997), Multi Methodolgy: Theory and Practice of Combining Management Science Methodologies. Wiley, Chichester.

Miser H. (1987). Science and professionalism in operations research. Operations Research; 35, 314-319.

Miser, H. (2000), George Mitchell's socks. Omega, 225-228,

Mitchell, G. (2000) Socks and cases. Omega, 235.

Muller-Merbach, H. (1994), “A System of System Approaches”, Interfaces, 24, pp16-25

Oral M, Kettani O. (1993), The facets of the modelling and validation process in operations research. European Journal of Operational Research; 66, 2, 216-234.

Pierskalla WP. (1987). Creating Growth in OR/MS. Operations Research; 35, 153-156

Reisman A, Oral M, Gattoufi S. (2003) Absolutely positively operations research: 50 years of contributions by William Wager Cooper. Working Paper SUGSM - 02-10. Sabanci University, Istanbul, Turkey. Forthcoming in Socio-Economic Planning Sciences.

Reisman, A. (1972) Burton V. Dean, Muhittin Oral, Michael Salvador, Industrial Inventory Control, Gordon and Breach, New York, 180 pages,

Reisman, A. (1979) Systems Analysis in Health-Care Delivery, Lexington Books, Lexington, Mass. 311 pages

Reisman, A. "OR/MS Education: A Need for Course Correction" (1995), The International Journal of Operations and Quantitative Management, Vol. 1, No. 1 pp. $67-76$

Reisman, A. (1966) "The Analysis and Synthesis of Production and Operations Systems: An Analytical Approach Bridging all Technologies", pp.122-139 in Integration of Technologies, L. Holiday, Ed., Hutchinson of London, London, England,. (A selection of essays sponsored by the British Association for the Advancement of Science and the Shell Chemical Co., Ltd.).

Reisman, A. and E.S. Buffa, (1964) "A General Model for Production and Operations Systems”, Management Science, No.1, 11, pp.64-79, September. Also pp.53-77 in Readings in Production and Operations Management, edited by E.S. Buffa, John Wiley \& Sons, Inc., 1966, New York

Reisman, A. and F. Kirschnick. (1994) "The Devolution of OR/MS: Implications From a Statistical Content Analysis of Papers in Flagship Journals". Operations Research. Vol.42(4), pp. 577-588.

Reisman, A. and F. Kirschnick. (1995) "Research Strategies Used by OR/MS Workers as Shown by an Analysis of Papers in Flagship Journals". Operations Research, Vol. 43,(5), pp. 731-740.

Research?. Operations Research 1993; 41, 625-640.

Roche, J.G. (2002) Operations Research in a New Era of National Security OR/MS TODAY, December, pp. 22-24 
Saaty, T. L., (2000) "Reflections and Projections on Creativity in Operations Research and Management Science: A Pressing Need for a Shift in Paradigm" Operations Research; 46 pgs 9-16

Shroff, V. Gurpreet Kahlon and Richard Huntrods, "Checkland's Soft Systems Methodology" December 7, 2000 from world wide web

Smith, A. (2000), George Mitchell's socks: Jones the Technologist. Omega 233-234

Tidman, K.R. (1984), The operations research group: A history of naval operations research. Naval Institute Press, Annapolis, MD. .

Underwood, J. (1996). "Models for Change - Soft Systems Methodology" Vol.7 No. 5, pp. 13-16, MCB University Press

Ulrich, W. (2003), "Beyond Methodology Choice: Critical Systems Thinking as Criticall Systemic Discourse", Journal of the Operational Research Society, 54, 325-342.

Wagner, H.M., Rothkopf, M.H., Thomas, C. J. and Miser H.J. "The Next Decade in Operations Research: Comment on the CONDOR Report" Operations Research; 37 pgs 664-672.

White, J.A., (1991) “An Existence Theorem for OR/MS” Operations Research; 39 pgs 183193.

Winter, M. (2000) "The Relevance of Soft Systems Thinking” Human Resource Development International” Vol 3, Issue 3

Winter, M., (2000) "The Relevance of Soft Systems Thinking” Human Resource Development International” Vol 3, Issue 3

\section{APPENDIX A}

The non-SST Literature: Articles in archival journals, chapters in books and books dedicated to addressing the philosophic or theoretic notions underlying SST

Abbott A. (1988) The system of professions: an essay on the expert division of labor. University of Chicago Press, Chicago, IL.

Ackoff, R.L., and Rivett, P. (1963), A Managers Guide to Operations Research. John Wiley and Sons, New York.

Ackoff, R.L. (1973), "Science in the Systems Age: Beyond IE, OR, and MS", Operations Research 21, 661-671.

Ackoff, R.L. (1977), "National -development planning revisited", Operations Research 25/2, 207-218.

Ackoff R. (1987) "OR: A Post Mortem". Operations Research; 35, 471-474.

Ackoff, R.L. (1979), "The future of Operational Research is Past", Journal of the Operational Research Society 30, 93-104.

Assad, A.A., Wassil, E.A. and Lillien, G.L. (1992). Excellence in Management Science Practice. Prentice-Hall, Englewood Cliffs. 
Avison, D. E., Eardley, W. A. and Powell, P. (1998). "Suggestions for capturing corporate vision in strategic information systems." Omega. 26/4 443-459

Banville, C. (1990), "Legitimacy and cognitive mapping: An exploratory study of a social dimension of organizational information systems", Unpublished Ph.D. Dissertation, Faculte des Sciences de l'Administration, Universite Laval, Quebec.

Barlas, Y. (1985), "Validation of system dynamics models wit; a sequential procedure involving multiple quantitative methods", Ph.D. Dissertation, Georgia Institute of Technology, Atlanta, GA 30332.

Barlas, Y. (1989), "Multiple tests for validation of system dynamics type of simulation models", European Journal of Operational Research 42/1, 59-87.

Barlas, Y., and Carpenter, S. (1990), "Philosophical roots of model validation: Two paradigms", System Dynamics Review 6/2, 148-166.

Beer, S. (1984), "The viable system model: Its provenance, development, methodology and pathology", Journal of the Operational Research Society .35/1, 7-25.

Blackett, P.M.S. (1962). Studies of war. Hilland Wang, New York.

Blair, L.H., Hatry, H.P., DonVito, P.A. (1970). Measuring the Effectiveness of Local Government Services: Solid Waste Collection. The Urban Institute. Washington D.C.

Blumstein, A. (1987) "The current Missionary role of OR/MS". Operations Research; 35, 926929.

Brigham, G. (1955). "On a Congestion Problem in an Aircraft Factory". Operations Research. 3 $412-428$

Brunsson, N. (1990), "Deciding for responsibility and legitimation: Alternative interpretations of organizational decision-making", Accounting, Organizations, and Society 15/(1-2), 47-59.

Churchman, C.W. (1968) The Systems Approach. Dell.

Churchman, C.W. (1961) Prediction and Optimal Decision. Prentice-Hall, Englewood Cliffs.

Churchman, C.W. (1971), The Design of Inquiring Systems. Basic Books, New York.

Churchman, C.W., Ackoff, R.L., Arnoff, E. L. (1957). Introduction to Operations Research. John Wiley and Sons, New York.

Corbett CJ, Van Wassenhove LN. “The Natural Drift: What Happened to Operations Research?". Operations Research 1993; 41, 625-640.

Cornoford, T., Donkidis, G.I. and Forster, D. (1994). "Experience with a structure, process, and outcome framework for evaluating an information system". Omega. 22/5 491-504

Coyle R.G., (1979). Management Systems Dynamics. John Wiley and Sons, Chichester, New York.

Davies, M. Eddison R.T., and Thornton, P. Eds. (1997). Proceedings of the First International Conference on Operational Research. Operations Research Society of America, Baltimore.

Denizel M, Usdiken B, Tuncalp D. "Drift or Shift? Continuity and International Variation in Knowledge Production in OR/MS", Working Paper SUGSM - 02 -18, Sabanci University, Istanbul, Turkey 2002. Forthcoming in Operations Research.

Dery, R. Landry, M. and Banville, C. (1993) "Revisiting the issue of model validation in OR: An epistemological view", European Journal of Operational Research 66/2, 168-183

Eden, C. (1988), "Cognitive mapping", European Journal of Operational Research 36/1, 1-13.

Eden, C., and Jones, S. (1984), "Using repertory grids for problem construction", Journal of the Operational Research Society 35/9, 779-790.

Edie, L.C. (1954). "Traffic Delays at Toll Booths". Operations Research. 2 107-138.

Finlay, P.N., and Wilson, J.M. (1987), "The paucity of model validation in Operational Research projects", Journal of the Operational Research Society 38/4, 303-308.

Forrester, J.W. (1961), Industrial Dynamics, MIT Press, Cambridge, MA.

Forrester, J.W. (1969), Urban Dynamics, MIT Press, Cambridge, MA.

Forrester, J.W. (1971), World Dynamics, Wright Allen Press, Cambridge, MA.

Forrester, J.W. (1973), "Confidence in models of social behavior with emphasis on system dynamics models", System Dynamics Group, Working Paper D-1917, Sloan School of Management, MIT, Cambridge, MA.

Forrester, J.W. (1980), "Information sources for modeling the national economy", Journal of the American Statistical Association, Applied Section 75(371), 555-579. 
Forrester, Jay W., 1994. "System Dynamics, Systems Thinking and Soft OR". Systems Dynamics Review. Vol: 10,No:2

Fortuin, L., Van Beek, P. and Van Wassenhove, L. (1996). OR at Work: Practical Experiences of Operational Research. Taylor and Francis, Ltd. London.

Gass, S.I. (1977), "Evaluation of complex models", Computers \& Operations Research 4/1, $27-35$.

Gass S.I. Ed. (1980) Validation and assessment issues of energy models. Proceedings of a workshop (NBS Special Publication 569).

Gass, S.I. (1983), "Decision-aiding models: Validation, assessment, and related issues for policy analysis", Operations Research 31/4, 603-631.

Gass, S.I., and Joel, L.S. (1981), "Concept of model confidence", Computers \& Operations Research 8/4, 341-346.

Glans, T.B., Grad, B., Holstein, D., Meyers, W. E. and Schmidt, R. N., (1968) Management Systems, Holt Reinhardt and Winston, New York.

Islei, G., Lockett, G. and Nande P., (1998). "Judgmental modeling as an aid to scenario planning and analysis". Omega. 27 61-73

Hermann, C.C., and Magee, J.F. (1953). "Operations Research for Management". Harvard Business Review. 3 July August.100-112.

Jackson, M.C., and Keys, P. (1984), "Towards a system of systems methodologies" Journal of the Operational Research Society 35/6, 473-486.

Johnston, R. A., Kost, F.E., Rosenzweig, J.E., (1963) The Theory and Management of Systems. McGrawHill Book Co. New York.

Journal of Operational Research Society. (1982). Special April Issue on "The practice of decision analysis". 334

Kahn, H. and Mann, J. (1956). Techniques of Systems Analysis. RM-1829, The Rand Corporation. Santa Monica, California.

Kahn, H. and Mann, J. (1957). The Common Pitafalls. RM-1937, The Rand Corporation. Santa Monica, California.

Kelly, G.A. (1955), The Psychology of Personal Constructs: A Theory of Personality, Norton, New York.

Koopman, B.O. (1956), "Fallacies in Operation Research", Address to the Fourth Annual Meeting of the Operation Research Society of America. May 10

Landry, M., Malouin, J.L., and Oral, M. (1983), "Model validation in Operations Research", European Journal of Operational Research 14, 207-220.

Landry, M., Banville, C., and Oral, M. (1996), "Model legitimisation in Operational Research", European Journal of Operational Research 92, 443-457.

Levin, R.I., Kirkpatrick, C. A., Rubin, D. S. (1965). Quantitative Approaches to Management, McGrawHill Book Co. New York.

Lilien, G.L. (1975) "Model relativism: A situational approach to model building" Interfaces 5/3

Lilien, G.L. and Rao, A. G. (1976). "A model for allocating retail outlet building resources across market areas". Omega. 241 1-14

Majone, G.. (1980). The Craft of Applied System Analysis. WP-80-73, International Institute of Applied System Analysis. Laxenbug, Austria.

Malouin, J.-L., and Landry, M. (1983), "The mirage of universal methods in system design", Journal of Applied System Analysis 10, 47-62.

Mason, R.O. and Mitroff, I.I. (1981). Challenging Strategic Planning Assumptions-Theory, Cases and Techniques. Wiley, New York

McCloskey, J.F., Trefethen, F.N., Eds. (1954). Operations Research for Management. John Hopkins Univeristy Press. Baltimore.

Meadows, D.L., Meadows, D.H., Randers, I., and Behrend W.W. (1972), Limits to Growth, Universe Books, New York.

Meadows, D.L., Behrens, W.W., Meadows, D.H., Naill, R.F., Randers, J., and Zahn, E.K.O. (1974), Dynamics of Growth in a Finite World, Wright-Allen Press.

Mintzberg, H., (1980) "Beyond implementation: An analysis of the resistance to policy analysis" INFOR, 18/2 100-138.

Miser, H.J. (1991), "Toward a philosophy of Operational Research", INFOR 29/1, 4-13. 
Miser, H.J. Ed.(1995), Handbook of Systems Analysis, Volume Two - Craft Issues and Procedural Choices. John Wiley and Sons, Chichester, New York.

Miser, H.J. and Quade E.S. Ed. (1995), Handbook of Systems Analysis, Volume Three - Cases. John Wiley and Sons, Chichester, New York.

Mitchell G. (1993) The Practice of Operational Research. John Wiley and Sons, Chichester, New York.

Morse, P.M. (1986), "The beginnings of operations research in the United States". Operations Research, 34 10-17

Muller-Merbach, H. (1984), "Interdisciplinarity in Operational Research - In the past and in the future", Journal of the Operational Research Society 35/2, 83-89.

Murphy, F.H. (1986), "Model assessment in the context of policy analysis", OMEGA 14/1, 35-48.

Naylor, T.H., and Finger, J.M., (1967) "Verification of Computer simulation models" Management Science, 15, 92-101

Nissen, D. (1980)“The impact of assessment on the modeling process”. in S.I. Gass Ed. Validation and assessment issues of energy models. Proceedings of a workshop (NBS Special Publication, 569, 1980.

Oral $\mathrm{M}$, Kettani $\mathrm{O}$. The facets of the modelling and validation process in operations research. European Journal of Operational Research 1993; 66, 2, 216-234.

Ormerod, R.S., (1996). "Combining management consultancy and research." Omega. 24/1 1-12

Palding, E. and Lackett, A. G. (1982). "Attitudes and perceptions relating to implementation and success." Journal of the Operational Research Society 33, 713-744

Pidd, M., and Woolley, R.N. (1980), "A pilot study of problem structuring", Journal of the Operational Research Society 31, 1063-1068.

Pounds, W.F. (1969), "The process of problem finding", Industrial Management Review 11, 1-9.

Quade, E. S. Ed. (1964). Analysis of Military Decisions. North Holland Press. Amsterdam.

Randers, J. (ed) (1980), The Elements of System Dynamics, The MIT Press, Cambridge, MA.

Ravetz, LR (1971), Scientific Knowledge and Its Social Problems, Oxford University Press, Oxford.

Reisman A. (1992). Management science knowledge: It's creation, generalization and consolidation. Westport CT: Quorum Books Publishing Company.

Richels, R. (1981) "Building good models is not enough" Interfaces, 11/4 48-54

Rosenheadm, J.J. (1989). Rational Analysis for a Problematic World: Problem Structuring Methods for Complexity, Uncertainty and Conflict. Wiley, Chichester, New York.

Roy, H.J.H. (1958). "Operations Research in Action”. Harvard Business Review. 36 september October.120-128

Sauter, V. (1985) "The effect of 'experience' on information preferences" Omega. 13/4 277-284

Schon, D.A. (1983), The Reflective Practitioner: How Professionals Think in Action, Basic Books, New York.

Smith, G.F. (1988), "Towards a heuristic theory of problem structuring", Management Science 34/12, 1489-1506.

Smith, G.F. (1989), "Defining managerial problems: A framework for prescriptive theorizing", Management Science 35/8, 963-981.

Smith, I.H. (1992), "Modeling muddles: Validation beyond the numbers", European Journal of Operational Research 66/2, 245-249 (this issue).

Stainton R.S. (1979) "Modeling and reality", Journal of the Operational Research Society 30/12,1031-1036.

Stringer, J. (1967). Operational Research for multi organizations. Operational Research Quarterly, 18 105-120

Tacket, A. and White, L., "Doing community operations research with multicultural groups". Omega. 22/5 579-588

Tidman, K.R. (1984), The operations research group: A history of naval operations research. Naval Institute Press, Annapolis, MD.

Toulmin, S. (1958), The Use of Argument, Cambridge University Press, Cambridge, England.

Van Horn, R.L (1971), "Validation of simulation results", Management Science 17/5, 247-258.

Vennix, J.A.M., Gubbels, J.W., Post, D., and Poppen, H.J. (1990), "A structured approach to knowledge elicitation in conceptual model building", System Dynamics Review 6/2, 194-208.

Woolley, R.N., and Pidd, M. (1981), "Problem structuring - A literature review", Journal of the Operational Research Society 32, 197-206. 
Yewlett, C.J.L (1984), "Polishing practice - The reconciliation of scientists and practitioners", Journal of the Operational Research Society. 35/6 487-498

\section{APPENDIX B}

\section{Articles in archival journals and chapters in books describing studies using the underlying concept of $\mathrm{SST}^{22}$ :}

M. Oral, M. Salvador, A. Reisman and B.V. Dean, (1972) "On the Evaluation of Shortage Costs for Determining Inventory Control Policies", Management Science, Vol.18, No.6, pp.B-344-351, February

A. Reisman, W. Cull, H. Emmons, B. Dean, C. Lin, T. George, J. Rasmussen, P. Darukhanavala, (1977) "On the Design of Alternative Obstetric Anesthesia Team Configurations", Management Science, Vol.23, No.6, February, pp.545-556.

S.J. Mantel, Jr., A. Service, A. Reisman, R.A. Koleski, A. Blum, B.V. Dean, R. Reich, M. Jaffee, H. Rieger, R. Ronis and J. Rubinstein, (1975) "A Social Service Measurement Model", Operations Research, Vol.23, No.2, pp.218-240, March-April,

M.D. Mesarovic and A. Reisman (1972), (eds.), Systems Approach and the City, North Holland Publishing Co., Amsterdam, 480 pages, 1972.

A.Reisman, (1972) Burton V. Dean, Muhittin Oral, Michael Salvador, Industrial Inventory Control, Gordon and Breach, New York, 180 pages,

A. Reisman, (1992) Management Science Knowledge: It's Creation, Generalization and Consolidation, (1987) Quorum Books Publishing Company, Westport, CT, 495 pages

A. Reisman,( 1987) Enfoque de Sistemas en la Administracion de Materiales en Hospitals, Washington, D.C., Pan American Health Organization, PNSP/83-36, 160 pages, 1983.

Second Edition

A. Reisman, (1979) Systems Analysis in Health-Care Delivery, Lexington Books, Lexington, Mass. 311 pages

A. Reisman and C. deKluyver, (1975) "Strategies for Implementing Systems Studies", Implementing Operations Research/Management Science, R.L. Schultz and D.P. Slevin (Eds.), American Elsevier Publishing Co., pp.291-310

A. Reisman, R. Occhionero, S. Morito, T. Nunnikhoven, H. Emmons, E. Green, S. Mehta, (1975)“Dental Practice Management: The Economics of Staffing and Scheduling”, North Holland/TIMS Studies in Management Sciences, Vol.1, pp.162-184, North Holland/American Elsevier Publishing Co.,

A. Reisman, H. Emmons, S. Morito, T. Nunnikhoven, S. Mehta, R. Occhionero, E. Green, (1975) "Dental Practice Management: The Economics of Staffing and Scheduling", North Holland/TIMS Studies in the Management Sciences, Vol.1, Logistics, Murray Geisler (Ed.), pp.161-184.

\footnotetext{
${ }^{22}$ These are not arranged alphabetically nor chronologically. They are presented in the order of accessibility to the OR/MS research community.
} 
A. Reisman, S. Morito, J. Rivaud, H. Emmons, E. Green, (1981) "Application of Simulation Gaming to Dental Practice Management", Applications of Management Science, Vol.1, JAI Press Inc., Greenwich, Conn.

A. Reisman et.al., (1969) "The Application of Operations Research to Community Planning", May 1969, Journal of Jewish Communal Service, Vol.XLVI, No.1, pp.70-92, New York, September A.L. Service, S.J. Mantel, Jr. and A. Reisman, (1972) "Systems Evaluation of Social Agencies", Systems Approach and the City, M.D. Mesarovic, A. Reisman (Eds.), North Holland Publishing Co., Amsterdam

A.L. Service, S.J. Mantel, Jr. and A. Reisman, (1972) "Systems Evaluation of Social Agencies", Systems Approach and the City, M.D. Mesarovic, A. Reisman (Eds.), North Holland Publishing Co., Amsterdam

B. Pollack-Johnson, B.V. Dean, A. Reisman and A. Michenzi, (1990) "Predicting Doctorate Production in the USA: Some Lessons for Long-Range Forecasters", International Journal of Forecasting, 6, No.1, pp.39-52

B.V. Dean, A. Reisman, and P. Darukhanavala, (1973) "Are you Looking for a New Plant Location?", Automation, Vol.2, No.11, pp.48-52, November

J.P. Herling, M.G. Fancher Beeler, A. Reisman, B.V. Dean, (1974) "Improved Delivery of Library Materials: The Cleveland Experience”, Journal of Library Automation, Vol.7, No.4, pp.275-290, December

A. Reisman, H. Emmons, S. Morito, J. Rivaud, E. Green, (1978). "Planning a Dental Practice with a Management Game", Journal of Medical Systems, Vol.2, No.1, October, pp.71-83. A. Reisman and B.V. Dean, (1973) "The Evaluation of Outputs of Health, Education and/or Welfare Programs in Local Agencies", First Annual Systems Engineering Conference, AIEE in New York, Technical Papers, November 28-30, pp.109-121.

S. Morito, A. Reisman, H. Emmons, J. Rivaud, (1977) "On Designing and Implementing a Dental Practice Management Game", Proceedings of the 1977 Winter Simulation Conference, National Bureau of Standards, December , pp.440-447.

A. Reisman, B.V. Dean, A.O. Esogbue, V.V. Aggarwal, V.B. Kaujalgi, P.M. Lewy, J.S. Gravenstein and C.A. deKluyver, (1973) "Supply and Demand of Anesthesiologists in Cuyahoga Country, Ohio", Ohio State Medical Journal, Vol.69, No.10, pp.760-763, October

A. Reisman, P. Frieder, L. Orfirer, E. Mulcahy, S. Morito, K. Mathur, S. Kulkarni, (1980) "Computer-Aided Practice Management for the Medical Profession", July , Montreal, Proceedings of the International Conference Systems Science and Health Care, Vol.II, 1981.

E. Mulcahy, L. Unger, P. Frieder, A. Reisman, S. Kulkarni and K. Mathur, (1981) "A Computerized Instrument for Practice Management Instruction", November 1981, Washington, D.C., Proceedings of the Fifth Annual Symposium on Computer Applications in Medical Care, Computer Society Press, pp.702-705

J.S. Gravenstein, B. Grundy, Y. Pao, A. Reisman, F. Staub, (1976) "The Cleveland Telemedicine Project", Telecommunications for Civic and Social Services, No.20, 1976 Wescon Professional Program Proceedings, Los Angeles, pp.1-2, September

A. Reisman, B.V. Dean, A.O: Esogbue, B.V. Aggarwal, V.B. Kaujalgi, P. Lewy, and J.S. Gravenstein, (1973) "Anesthesiology Manpower Planning in Cuyahoga County, Ohio", Health Care Delivery Planning, A. Reisman and M.L. Kiley, (Eds.), Gordon and Breach Science Publishers, New York, London and Paris 
A. Blum, B.V. Dean, R.A. Koleski, S.J. Mantel, Jr., A. Reisman, R. Ronis, J. Rubenstein, A.L. Service, M. Jaffee, R. Reich and H. Reiger, (1973) "A Measurement Model for Planning and Budgeting for Jewish Community Federation of Cleveland", Health Care Delivery Planning, A. Reisman and M.L. Kiley (Eds.), Gordon and Breach Science Publishers, New York, London and Paris

A. Reisman, B.V. Dean, V.B. Kaujalgi, B.V. Aggarwal and J.S. Gravenstein, (1973) "A Basis for Appropriate Training of Anesthesiology Personnel: A Task Analysis Approach", Health Care Delivery Planning, A. Reisman and M.L. Kiley, (Eds.), Gordon and Breach Science Publishers, New York, London and Paris

A. Reisman, E. Green, H. Emmons, S. Mehta, S. Morito, K. Dadachanji, R. Occhionero, (1974)“Economic and Management Considerations in the Practice of Team Dentistry", Dental Clinics of North America, Vol.18, No.4, October In the Interamericana Edition, Clinicas Odontologicas de Norteamerica.

B. Grundy, P. Crawford, P. Jones, M. Kiley, A. Reisman, Y. Pao, E. Wilkerson, J. Gravenstein, (1977) "Telemedicine in Critical Care: An Experiment in Health Care Delivery", Journal of the American College of Emergency Physicians and the University Association for Emergency Medicine, Vol.6, No.10, October

A. Reisman, H. Emmons, S. Morito, J. Rivaud, A. Chaudhuri, E. Green, (1977) "Dental Practice Management Game: A New Tool for Teaching Practice Management", Journal of Dental Education, Vol.41, No.5, May, pp.262-267.

A. Reisman, H. Emmons, S. Morito, J. Rivaud, A. Chaudhuri, E. Green, "On Setting up a Dental Practice with EFDA's (Expanded Function Dental Auxiliary)", Chapter 32, Vol.5, Clinical Dentistry, J.W. Clark, Editor, Harper \& Row 1978, pp.102-112.

A. Reisman, H. Emmons, S. Morito, J. Rivaud, (1978) "On the Development and Use of a Dental Practice Management Game", Challenges and Prospects for Advanced Medical Systems,Vol.2, No.1,, pp.41-50.

H. Simon, A. Reisman, S. Javad, D. Sachs, (1979) "An Index of Accessibility for Ambulatory Health Services", Medical Care, Vol.17, No.9, pp.894-901, September

A. Reisman, H. Emmons, S. Morito, J. Rivaud, E. Green, (1981) "Dental Management Game", Evanston, July 1979, Proceedings of the Conference on Modeling Techniques and Applications in Dentistry, Health Resources Administration, pp.238-262, March

N. Duraiswamy, R. Welton, A. Reisman, (1983) "Using Computer Simulation to Predict ICU Staffing Needs", The Journal of Nursing Administration, Vol.XI, No.2, pp.39-44, February 1981. Also Book of Readings, Education of Operational Research and System Analysis in Health Services Administration Programs, Serie Desarrollo de Recoursos Humanos No.50, Pan American Health Organization, Washington, D.C., June , pp.324-329.

A. Reisman, J. Silva, J. Mantell, (1983) "Systems and Procedures of Patients and Information Flow in the Outpatient Clinic of a Large Health Center", Hospital and Health Services Administration, Vol.23, No.1, pp.42-71, Winter 1978. Also Book of Readings, Education of Operational Research and System Analysis in Health Services Administration Programs, Serie Desarrollo de Resoursos Humanos No.50, Pan American Health Organization, June , pp.137166.

L. Duran, A. Reisman, (1983) "Design of Alternative Provider Team Configurations: Experience in Both Developed and Developing Countries", Book of Readings, Education of Operational Research and System Analysis in Health Services Administration Programs, Serie Desarrollo de Recoursos Humanos No. 50, Pan American Health Organization, Washington D.C., pp.205-228, June 
L. Duran, A. Reisman, J. Becerra, C. Regis,(1984) "Manpower Needs Forecasts for the Health Services of the United States of Mexico", Boletin de la OSP, Pan American Health Organization, Washington, D.C., pp.387-395, May

A. Reisman, K. Mathur, E. Mulcahy, (1984) "The CWRU Practice Management Game: A Painless Way for Physicians to Learn Managerial Skills", Journal of Health Administration Education, Vol.2, No.1, pp.65-74 